\title{
Spray drying conditions for protein hydrolysate of crocodile meat
}

\author{
${ }^{1,2}$ Hong, P.V.C., ${ }^{3}$ Tan, H.D., ${ }^{4}$ Thanh, P.T.T., ${ }^{5}$ Cang, M.H., ${ }^{1,2}$ Don, D.L. and ${ }^{3, *}$ Thien, L.T. \\ ${ }^{1}$ Research Institute for Biotechnology and Environment, Nong Lam University, Ho Chi Minh City, Vietnam \\ ${ }^{2}$ Biotechnology Department, Nong Lam University, Ho Chi Minh City, Vietnam \\ ${ }^{3}$ Faculty of Food Science and Technology, Nong Lam University, Ho Chi Minh City, Vietnam \\ ${ }^{4}$ School of Biotechnology, International University, Vietnam National University, Ho Chi Minh City, \\ Vietnam \\ ${ }^{5}$ Department of Chemical Engineering and Processing, Nong Lam University, Ho Chi Minh City, Vietnam
}

Article history:

Received: 18 July 2020

Received in revised form: 12

August 2020

Accepted: 8 September 2020

Available Online: 6

December 2020

Keywords:

Crocodile meat,

Protein hydrolysate,

Spray drying,

Surface response,

Antioxidant activity

DOI:

https://doi.org/10.26656/fr.2017.5(1).367

\begin{abstract}
The objective of this study is to screen the effects of several parameters (i.e., drying aid concentration, inlet air temperatures, and feed flow rates) on the spray drying process of crocodile meat protein hydrolysate. The results showed that the experimental parameters exhibited significant effects on recovery of dry matter, recovery of proteins and the obtained powder properties (total protein content, moisture content and antioxidant capacity). Besides, inlet air temperature and drying aid concentration also significantly impacted response variables. The conditions for maximum recovery of dry matter, maximum recovery of proteins, and minimum moisture content of the spray-dried powder were found at maltodextrin concentration of $19.47 \%(\mathrm{w} / \mathrm{w})$, inlet air temperature of $142.71^{\circ} \mathrm{C}$, and input feed flow rate of $10 \mathrm{~mL} / \mathrm{min}$. These conditions correspond to the recovery of dry matter of $69.51 \%$, protein recovery yield of $76.94 \%$, powder humidity of $5.33 \%$, and powder antioxidant activity of $1.87 \mathrm{mg} / \mathrm{mL}$.
\end{abstract}

\section{Introduction}

Crocodiles are considered to be more advanced than other reptiles. However, increased crocodile quantity requires further diversification of crocodile-based products in order to maximize the profit of crocodile farming. Currently, crocodile meat, which has certain economical potential, is considered as a by-product and marketed at a lower price compared to other kinds of meat. According to Beilken et al. (2007), crocodile meat is rich in protein, low in fat, and is nutritionally balanced which is suitable for human consumption. For example, it has been reported that Nile crocodile meat constitutes $22 \%$ of proteins $(220.8 \mathrm{~g} / \mathrm{kg})$ and only $6 \%$ of fat (Hoffman et al., 2000). Besides, crocodile meat is inexpensive and has high biological value, which is mostly contributed by the essential amino acids existing in the meat proteins, making the meat promising as an ingredient for the manufacture of supplement foods (Hoffman et al., 2000).

Since the essential amino acids, abundantly present in crocodile meat protein, are not universally digestible and absorbable (Kurozawa et al., 2011), it is necessary to improve bioactivities and bioavailability of protein through hydrolysis. To date, many procedures for processing crocodile meat protein hydrolysate has been developed and reported in the literature. Furthermore, biologically bioactive peptides provide several benefits for physiological functions of organisms in the human body such as antihypertensive, immunomodulation, antithrombotic, antioxidative, anticancer and antimicrobial activities (Clare et al., 2000). The antioxidant activity of peptides is first released in 1960 by Marcuse and until now, numbers of studies have been carried out to clarify its antioxidant properties (GómezGuillén et al., 2010). According to current knowledge, it is known that peptides are scavengers of free radicals and has the ability to inhibit lipid peroxidation and chelate transition metal ions (Suetsuna et al., 2000; Young et al., 2013). The antioxidant activity is affected by several factors such as type of amino acids, their numbers in the peptide, as well as the arrangement of amino acid sequences (Suetsuna et al., 2000). Based on previous studies Tyrosine, Tryptophan, Methionine, Cystine, Lysine and Histidine contribute to high antioxidant activity (Wang and De Mejia, 2005). 
Processing treatments (e.g., heating) may influence the antioxidant capacity of food substances.

Although protein hydrolysates have some certain potential, the preservation is quite difficult due to its high protein and moisture content (Kurozawa et al., 2011). This suggests the dehydration approach since the powder form is easier for preservation and more applicable. Based on the properties of protein hydrolysates, two techniques are suitable to maintain the nutritional values of the obtained powder product, namely freeze-drying and spray drying. Among the two methods, spray drying is preferred due to its superior cost-efficiency.

Spray drying is a well-established and widely used technique for conversion of liquid food products, including solution and suspension, into solid and semisolid particles (Kurozawa et al., 2011). The technique comprises three main stages including (1) formation of tiny droplets through the atomizing system, (2) drying of these droplets by hot air, (3) moving of the obtained powder into processing recovery system (Jayasundera et al., 2011).

Under the optimal conditions, spray drying is considered as a high-efficiency process (Shabde and Hoo, 2008). It is because spray drying operation could produce high-quality products that maintain almost full nutritional values due to the short exposure to high temperatures. Besides, the powder products have low water activity resulting in easier storage, transportation and formulation (Jittanit et al., 2010). However, the spray-drying operation is affected by numerous factors such as inlet air temperatures, feed flow rates, compressed air pressures, types and concentration of carrier agents, and types of the atomizer (Obón et al., 2009). For instances, high inlet air temperatures impact total protein content and antioxidant capacity of the protein hydrolysate powder. Nevertheless, conversion of protein hydrolysate into powder form by spray drying may have several problems of stickiness and high hygroscopicity (Yousefi et al., 2011). This is due to a wide range of low molecular peptides contained in protein hydrolysates that results in low glass transition temperature. The addition of carrier agents such as maltodextrin or gum Arabic, due to the presence of high molecular compounds contained within (Adhikari et al., 2007), can reduce stickiness and hygroscopicity of the protein hydrolysate during spray drying (Kurozawa et al., 2011). Thus, the addition of the carrier agent's help maintains the glassy state of protein hydrolysate during drying (Bhandari et al., 1997). Besides, added carrier agents also prevent the obtained powder from caking during storage (Adhikari et al., 2007). Maltodextrin was used successfully in spray drying chicken protein hydrolysates (Kurozawa et al., 2011). The feed flow rates also have certain influences on spray drying process since protein hydrolysates are high hygroscopicity (Samborska et al., 2015). To improve the recovery of process and quality of the obtained powder for a new spray drying application, the effects of the aforementioned factors should be considered.

Therefore, this study is designed to study the effects of spray drying parameters on spray drying of protein hydrolysate of crocodile meat.

\section{Materials and methods}

\subsection{Materials}

Crocodile meat, the main material of this study, was obtained from Hoa Ca Crocodile Company (District 12, Ho Chi Minh City). Firstly, skin, grease, and bone were removed. Then, the lean meat was washed carefully with tap water to remove dirt and other contaminations. After that, the lean meat was ground, mixed and divided into 1 $\mathrm{kg}$ plastic bags for storage at $-20^{\circ} \mathrm{C}$.

\subsection{Chemicals and other materials}

Maltodextrin (MD, $\mathrm{DE}=12)$ with a moisture content of $6.38 \%$ was purchased from Roquette Singapore Pte. Ltd. Sodium hydroxide, sulfuric acid $(98 \%$, Merck Germany, hydrochloric acid (37\%, Merck - Germany), boric acid, copper sulfate and indicator dye - methyl red using for protein determination that was purchased from Chinese chemicals. 2, 2'-azino-bis (3ethylbenzothiazoline-6-sulphonic acid) (ABTS) (Sigma Aldrich, Germany), potassium persulfate, phosphate, and ascorbic acid used for determination of antioxidant capacity were purchased from Merck Co. Ltd (Germany).

\subsection{Preparation of crocodile meat protein hydrolysate}

The protein hydrolysis was carried out based on a previously developed procedure (unpublished results). Firstly, ground crocodile meat was defrosted at room temperature. Then, the meat was mixed with distilled water (ratio of water: meat $=2: 1$ ), and the mixture was blended well by a hand blender. After that, the mixture was heated at $90-95^{\circ} \mathrm{C}$ for 15 mins to inactivate activities of crocodile meat enzymes. Before the hydrolysis enzymes neutral (SEB, India) and Alcalase ${ }^{\circledR}$ (Novozymes, Denmark)) were added, the $\mathrm{pH}$ of the mixture was adjusted to 7.0 by Sodium hydroxide $1 \mathrm{~N}$ in order to form a favorable medium for enzymatic activity. The total time of hydrolysis was $8 \mathrm{hrs}$. After that, the reaction was stopped by heating the solution at $85^{\circ} \mathrm{C}$ for 20 mins. Then, the protein hydrolysate was filtered with Whatman filter paper that has an aperture size of $11 \mu \mathrm{m}$. 
After removing sediment, total dry matter content of the protein hydrolysate was around $5.5 \%$. The protein hydrolysate was concentrated to $10 \%$ of total dry matter content using vacuum evaporation at $80^{\circ} \mathrm{C}$. After that, the protein hydrolysate was divided into containers, stored at $-20^{\circ} \mathrm{C}$, and thawed each time of use according to the quantity required. The total protein content of the ready-to-use hydrolysate for spray drying was around $9.12 \pm 0.5 \%$.

\subsection{Experimental design}

2.4.1 Effects of spray drying parameters on the recovery of dry matter, recovery of proteins, and the obtained powder properties.

Three preliminary experiments were carried out separately to screen the effects of maltodextrin concentrations $(0,10,20,30,40 \%, \mathrm{w} / \mathrm{w})$, inlet air temperature $\left(130,140,150,160^{\circ} \mathrm{C}\right)$ and feed flow rate $(5,10,15,20 \mathrm{~mL} / \mathrm{min})$. The concentration of the carrier agent was calculated by the weight of the carrier agent and weight of feed solution. The mixture was stirred well by magnetic stirring until complete dissolution. Then, the mixture was homogenized by an ultraturax homogenizer (IKA T18 digital ultraturax, Germany) at $11,000 \mathrm{rpm}$ for 5 mins. The homogenized mixture was defoamed by using an ultrasonic bath (Elma, Schmidbaer GmbH, Germany). Spray drying was performed using a laboratory-scale spray dryer (Lab Plant SD-Basic, Lab Plant UK Ltd., UK). The mixture (at $25^{\circ} \mathrm{C}$ ) was fed into the spray drying chamber through a peristaltic pump. The spraying was supported by a compressed air pump set at $0.2 \mathrm{MPa}$.

\subsubsection{Optimization of inlet air temperatures and} maltodextrin concentrations for optimal recovery of dry matter, recovery of proteins and moisture content of the obtained powder

The experiment was designed using surface response methodology (RSM) with a central composite design (CCD). Two variables (parameters), namely inlet air temperatures and added maltodextrin concentrations were considered. The ranges of values for these two parameters were taken based on the results of previous single factor experiments. The feed flow rate was fixed at $10 \mathrm{~mL} / \mathrm{min}$ and compressed air pressure at $0.2 \mathrm{MPa}$. The responses were the recovery of dry matter, recovery of proteins, and moisture content of the obtained powder.

Total number experimental units were calculated with the formula: $\mathrm{N}=2^{\mathrm{k}}+2 \mathrm{k}+\mathrm{n}$ (k is the factor of the experimental unit and $\mathrm{n}$ is the number of experimental units at central level). In this experiment, $k=2$ and $n=5$. Hence, the total number of experimental units was 13 . After using JMP to design the experiment, the code levels and spray drying parameters were obtained.

The range and center point values of two independent variables were based on the results of preliminary experiments. Five levels $(-\alpha,-1,0,1, \alpha)$ were explored for both, corresponding to inlet air temperature of $133,134,140,135$ and $147^{\circ} \mathrm{C}$ and maltodextrin concentration of $18.6,19,20,21$ and $21,4 \%(\mathrm{w} / \mathrm{w})$, respectively.

The experimental data were fitted into a secondorder model to obtain regression coefficients. The general second-order model utilized in the response surface analysis as follows:

$$
Y=a_{0}+a_{1} x_{1}+a_{2} x_{2}+b_{1} x_{1} x_{2}+c_{1} x_{1}{ }^{2}+c_{2} x_{2}^{2}
$$

With $a_{0}, a_{1}, a_{2}, b_{1}, b_{2}, c_{1}, c_{2}$ are coefficients of the regression. $\mathrm{x}_{1}, \mathrm{x}_{2}$ are the coded variables in which $\mathrm{x}_{1}$ was inlet air temperatures and $\mathrm{x}_{2}$ was maltodextrin concentrations. Optimized conditions were defined as the points where recovery of dry matter and recovery of proteins were maximized, or moisture content of the powder was minimized.

\subsection{Analysis}

\subsubsection{Determination of moisture content and dry matter content}

The total dry matter and moisture content were determined by oven method AOAC Method 2001-12 in which total dry matter was the remained residue after being evaporated by oven drying. The samples were placed in aluminum dishes and put into the oven. Samples were dried at $105^{\circ} \mathrm{C}$ until their weights remained constant.

\subsubsection{Determination of total protein content}

The total protein content of the obtained powder was determined by Kjeldahl method (Tonon et al., 2008) which bases on the total nitrogen content of the sample. The process was divided into three stages: digestion, distillation, and titration. First, samples were placed into the block digester in which each tube contained around $0.5 \mathrm{~g}$ of the sample, $15 \mathrm{~mL}$ of sulfuric acid and copper sulfate. After digestion, the nitrogen inside samples was converted into ammonium and the initial very dark colored medium has become clear and blue colored. During distillation, the solution was distilled with a small quantity of sodium hydroxide, which transfers the ammonium salt to ammonia. The end of the condenser was dipped into $50 \mathrm{~mL}$ boric acid. The mixture of ammonia and acid boric was titrated with hydrochloric acid in the titration stage.

The protein content was calculated with the formula:

$$
\mathrm{P}(\%)=((1.4 \times(\mathrm{V}-\mathrm{Vo}) \times \mathrm{N} \times \mathrm{f}) / \mathrm{M}
$$


Where $\mathrm{P}$ is the protein content in the sample (\%); $\mathrm{M}$ is the weight of the sample $(\mathrm{g}) ; \mathrm{V}$ is the volume of hydrochloric acid for titration of samples; Vo volume of hydrochloric acid for titration of the blank sample; $\mathrm{N}$ concentration of hydrochloric acid; f conversion factor (6.25).

\subsubsection{Determination of antioxidant capacity}

In this study, antioxidant capacity was determined by the ABTS method (Re et al., 1998). The blue ABTS ${ }^{+}$ turns into colorless ABTS-R + when ABTS $\bullet^{+}$reacts with an oxidizing solution. There were three stages in determining antioxidant capacity. Firstly, to form free radical $\mathrm{ABTS} \bullet^{+}$solution $7 \mathrm{mM}$ stock $\mathrm{ABTS}$ was mixed with potassium persulfate. Then, the mixture was incubated at room temperature for 12-16 hrs. Secondly, free radical $\mathrm{ABTS}^{+}$solution was diluted in phosphate solution ( $\mathrm{pH}$ 7.4) to form solution A. Diluted free radical ABTS $^{*}{ }^{+}$solution must have OD734nm $=0.70 \pm 0.02$. Thirdly, $50 \mu \mathrm{L}$ sample $(0-2000 \mu \mathrm{g} / \mathrm{mL})$ was added into solution A. The reaction duration was about 30 mins. The antioxidant capacity of the sample was expressed as $\mathrm{IC}_{50}$, which is defined as the concentration of the sample required to inhibit ABTS radical 50\%.

\subsubsection{Recovery of dry matter and proteins}

The recovery of dry matter and recovery of proteins were determined using the formulas.

Recovery of dry matter $=($ Total dry matter of powder $/$ total dry matter of feed solution) $\times 100$

Recovery of proteins $=($ Total protein content of powder/ total protein content of feed solution) $\mathrm{x} 100$

\subsection{Statistical analysis}

All the single factor experiments were carried out in triplicate. The results were analyzed by JMP 9.0.2 (SAS Institute Inc., 2011; USA). The experimental results were expressed as average values \pm standard deviations. Tukey's test was utilized to compare mean values when variances were found to be significant $(p<0.05)$. For the optimization experiment, the significance of the equation parameters for each response variable was analyzed by analysis of variance (ANOVA) and RSM was performed using the JMP 9.0.2 software. The model adequacy was evaluated through the coefficient of determination $\left(R^{2}\right)$.

\section{Results and discussion}

3.1 Effects of maltodextrin concentrations on the recovery of dry matter, recovery of proteins, and the obtained powder properties

Effects of maltodextrin concentrations suggest a significant reduction of total protein content corresponding with the increasing maltodextrin concentration due to the presence of residual maltodextrin compounds (Table 1). After feed solution was homogenized, maltodextrin compounds bound to dry matter compounds in protein hydrolysate. However, the excessive amount of maltodextrin compounds could result in residual maltodextrin, in turn occupying a portion of the total dry matter content of powder and reducing the total protein content.

In contrast, recovery of proteins was increased significantly when the concentrations of maltodextrin increased from $0 \%$ to $10 \%$. This can be explained by the higher hygroscopicity and stickiness of the control sample, which includes $0 \%$ maltodextrin, than those of the samples containing maltodextrin. Hence, a wide range of peptides was stuck inside the drying chamber, resulting in reduced recovery yield. When the concentration of maltodextrin rose past $10 \%$, the hygroscopicity and stickiness were found to be declining. Thus, the recovered proteins and recovered dry matter both increased. However, as the maltodextrin concentration increased from $30 \%$ to $40 \%$, the viscosity of feed solution becomes extravagant, causing dry matter to remain in the feed solution. Then, low molecular peptides were stuck in the drying chamber. Therefore, the recovery of proteins was reduced when maltodextrin concentration increased from $30 \%$ to $40 \%$. The moisture content of the produced powder was found to be decreasing with increasing maltodextrin concentration. The increase of solid content could lead to a reduction of free feed water content for evaporation, and in turn, lower moisture content of the powder (Re et al., 1999). Furthermore, maltodextrin is a high molecular compound

Table 1. Effects of maltodextrin concentrations on the recovery of dry matter, recovery of protein, and total protein content and moisture content of the obtained powder

\begin{tabular}{ccccc}
\hline Added maltodextrin & Recovery of dry & Moisture content & $\begin{array}{c}\text { Total protein } \\
\text { content }(\% \mathrm{w} / \mathrm{w})\end{array}$ & Recovery of \\
\hline 0 & $60.38 \pm 1.11^{\mathrm{a}}$ & $7.57 \pm 0.08^{\mathrm{d}}$ & $91.74 \pm 0.08^{\mathrm{a}}$ & $67.68 \pm 1.34^{\mathrm{a}}$ \\
10 & $62.52 \pm 1.02^{\mathrm{b}}$ & $6.56 \pm 0.09^{\mathrm{c}}$ & $54.42 \pm 0.55^{\mathrm{b}}$ & $82.68 \pm 2.12^{\mathrm{b}}$ \\
20 & $68.67 \pm 0.75^{\mathrm{c}}$ & $4.82 \pm 0.09^{\mathrm{b}}$ & $30.82 \pm 0.49^{\mathrm{c}}$ & $82.23 \pm 0.45^{\mathrm{c}}$ \\
30 & $69.15 \pm 0.39^{\mathrm{c}}$ & $4.77 \pm 0.04^{\mathrm{b}}$ & $21.36 \pm 0.43^{\mathrm{c}}$ & $85.74 \pm 1.30^{\mathrm{c}}$ \\
40 & $73.08 \pm 0.23^{\mathrm{d}}$ & $4.28 \pm 0.05^{\mathrm{a}}$ & $12.8 \pm 0.54^{\mathrm{b}}$ & $77.95 \pm 3.45^{\mathrm{b}}$ \\
\hline
\end{tabular}

Values are mean \pm standard deviation of triplicate samples. Values with different superscript within the column are significantly different (Tukey's Test, $\mathrm{p}<0.05$ ). 
that is less hygroscopic. Thus, higher maltodextrin concentration in the powder could reduce its moisture content. The recovery of dry matter was found to be increasing with rising maltodextrin concentration due to the reduction of hygroscopicity and stickiness. Based on the above results, $20 \%$ was selected as the most appropriate concentration for investigation of the effects of inlet air temperatures, feed flow rates, and optimization.

\subsection{Effects of inlet temperatures on the recovery of dry} matter, recovery of proteins, and the obtained powder properties

The results showed that the moisture content of the powder was reduced as the temperature increased (Table 2 ). This is possibly due to higher inlet air temperature leading to faster heat transfer between the protein hydrolysate and drying air. For instances, the increase of temperature gradient between the protein hydrolysate and drying air may exert driving force for water evaporation (Shabde and Hoo, 2008).

As the temperature rises from $130^{\circ} \mathrm{C}$ to $140^{\circ} \mathrm{C}$, the total protein content of powder and recovery of proteins increased significantly. It is due to the higher hygroscopicity of low molecular peptides than those of maltodextrin compounds. Thus, at a lower temperature $\left(130^{\circ} \mathrm{C}\right)$, the amount of sticky proteins was higher than that observed at a higher temperature $\left(140^{\circ} \mathrm{C}\right)$. The total protein content and recovery of proteins were reduced when temperature increased from $150^{\circ} \mathrm{C}$ to $160^{\circ} \mathrm{C}$ due to the heat sensitivity of proteins. Furthermore, the recovery of dry matter was increased with rising inlet air temperature. According to Tonon et al. (2008) and Samborska et al. (2015), the increase of inlet air temperature produces higher recovery of dry matter due to higher mass and heat transfer.

Based on Table 2, the $\mathrm{IC}_{50}$ of the powder obtained at $140^{\circ} \mathrm{C}, 150^{\circ} \mathrm{C}$ and $160^{\circ} \mathrm{C}$ were all lower than that those at $130^{\circ} \mathrm{C}$. Thus, the antioxidant capacity of powder at $140^{\circ} \mathrm{C}, 150^{\circ} \mathrm{C}$ and $160^{\circ} \mathrm{C}$ were higher than the antioxidant capacity of the sample at $130^{\circ} \mathrm{C}$. As previously mentioned, the antioxidant capacity of protein hydrolysate depends on its amino acids content. Thus, the amino acids of the powder sample at $140^{\circ} \mathrm{C}, 150^{\circ} \mathrm{C}$ and $160^{\circ} \mathrm{C}$ had high antioxidant capacity compared to amino acids of the powder sample at $130^{\circ} \mathrm{C}$. Besides, the protein content of powder at $140^{\circ} \mathrm{C}$ and $150^{\circ} \mathrm{C}$ was higher than protein content at $130^{\circ} \mathrm{C}$. Based on the above results, $140^{\circ} \mathrm{C}$ was the appropriate temperature for the next experiments.

3.3 Effects of feed flow rates on the recovery of dry matter, recovery of proteins, and the obtained powder properties (total protein content and moisture content)

The results showed that increasing of feed flow rate from 15 to $20 \mathrm{~mL} / \mathrm{min}$ adversely affects the spray drying of protein hydrolysate (Table 3). This is because the feed solution, when subjected to high speed, was not atomized before entering the drying chamber. Thus, the moisture content of the powder increased significantly due to low heat and mass transfer (Samborska et al., 2015).

The recovery of dry matter was declining since dry matter components were stuck in the drying chamber, especially low molecular peptides which have high

Table 2. Effects of inlet air temperatures on the recovery of dry matter, recovery of protein, and total protein content; moisture content and antioxidant capacity of the obtained powder

\begin{tabular}{cccccc}
\hline $\begin{array}{c}\text { Temperature } \\
\left({ }^{\circ} \mathrm{C}\right)\end{array}$ & $\begin{array}{c}\text { Recovery of dry } \\
\text { matter }(\%)\end{array}$ & $\begin{array}{c}\text { Moisture content } \\
(\% \mathrm{w} / \mathrm{w})\end{array}$ & $\begin{array}{c}\text { Total protein } \\
\text { content }(\% \mathrm{w} / \mathrm{w})\end{array}$ & $\begin{array}{c}\text { Recovery of } \\
\text { proteins }(\%)\end{array}$ & $\mathrm{IC}_{50}(\mathrm{mg} / \mathrm{mL})$ \\
\hline 130 & $59.92 \pm 0.58^{\mathrm{a}}$ & $6.72 \pm 0.11^{\mathrm{d}}$ & $24.52 \pm 0.66^{\mathrm{c}}$ & $59.27 \pm 0.95^{\mathrm{a}}$ & $4.134 \pm 0.056^{\mathrm{b}}$ \\
140 & $66.27 \pm 0.58^{\mathrm{b}}$ & $5.49 \pm 0.15^{\mathrm{c}}$ & $30.01 \pm 0.30^{\mathrm{b}}$ & $77.76 \pm 0.26^{\mathrm{b}}$ & $3.548 \pm 0.193^{\mathrm{e}}$ \\
150 & $69.06 \pm 0.24^{\mathrm{c}}$ & $4.77 \pm 0.13^{\mathrm{b}}$ & $30.77 \pm 0.45^{\mathrm{b}}$ & $82.46 \pm 1.12^{\mathrm{c}}$ & $3.819 \pm 0.033^{\mathrm{c}}$ \\
160 & $69.65 \pm 0.64^{\mathrm{c}}$ & $4.35 \pm 0.04^{\mathrm{a}}$ & $21.42 \pm 0.37^{\mathrm{a}}$ & $57.64 \pm 1.23^{\mathrm{a}}$ & $3.813 \pm 0.151^{\mathrm{d}}$ \\
\hline
\end{tabular}

Values are mean \pm standard deviation of triplicate samples. Values with different superscript within the column are significantly different (Tukey's Test, $\mathrm{p}<0.05$ ).

Table 3. Effects of feed flow rates on the recovery of dry matter, recovery of proteins and, total protein content and moisture content of the obtained powder

\begin{tabular}{ccccc}
\hline $\begin{array}{c}\text { Feed flow rates } \\
(\mathrm{mL} / \mathrm{min})\end{array}$ & $\begin{array}{c}\text { Recovery of dry } \\
\text { matter }(\%)\end{array}$ & $\begin{array}{c}\text { Moisture content } \\
(\% \mathrm{w} / \mathrm{w})\end{array}$ & $\begin{array}{c}\text { Total protein } \\
\text { content }(\% \mathrm{w} / \mathrm{w})\end{array}$ & $\begin{array}{c}\text { Recovery of } \\
\text { proteins }(\%)\end{array}$ \\
\hline 5 & $68.92 \pm 0.76^{\mathrm{b}}$ & $4.82 \pm 0.04^{\mathrm{a}}$ & $29.31 \pm 0.43^{\mathrm{b}}$ & $78.4 \pm 1.54^{\mathrm{b}}$ \\
10 & $67.91 \pm 0.27^{\mathrm{b}}$ & $4.93 \pm 0.03^{\mathrm{a}}$ & $29.34 \pm 0.64^{\mathrm{b}}$ & $77.35 \pm 1.83^{\mathrm{b}}$ \\
15 & $67.15 \pm 0.80^{\mathrm{b}}$ & $5.20 \pm 0.09^{\mathrm{b}}$ & $29.32 \pm 0.34^{\mathrm{b}}$ & $76.68 \pm 1.68^{\mathrm{b}}$ \\
20 & $50.44 \pm 0.76^{\mathrm{a}}$ & $5.98 \pm 0.03^{\mathrm{c}}$ & $21.22 \pm 0.32^{\mathrm{a}}$ & $42.03 \pm 1.20^{\mathrm{a}}$ \\
\hline
\end{tabular}

Values are mean \pm standard deviation of triplicate samples. Values with different superscript within the column are significantly different (Tukey’s Test, $\mathrm{p}<0.05$ ). 
hygroscopicity value. The total protein content and recovery of proteins were also in similar trends. However, as revealed by the Tukey's test, except for moisture content, the results of the three remaining indicators were insignificantly different throughout the first three flow rate levels. Based on the value of moisture content, two feed flow rate levels, $5 \mathrm{~mL} / \mathrm{min}$ and $10 \mathrm{~mL} / \mathrm{min}$ were suitable for the next experiment. However, since $10 \mathrm{~mL} / \mathrm{min}$ has shorter drying time, it was selected for the next experiment.

3.4 Optimization of inlet air temperatures and maltodextrin concentrations for the highest recovery of dry matter and proteins, and the lowest moisture content of the powder

Table 4 shows the values of recovery of dry matter, recovery of proteins, moisture content and powder antioxidant activity for each experimental attempt obtained from the optimization experiment. As discussed in the method, the multiple linear regression analysis of experimental data was distributed by these results. The second-order polynomial for three responses was described by the Equation (5), Equation (6), Equation (7) and Equation (8) for recovery of dry matter $\left(\mathrm{y}_{1}, \%\right)$, recovery of protein $\left(\mathrm{y}_{2}, \%\right)$, moisture content $\left(\mathrm{y}_{3}, \% \mathrm{w} /\right.$ $\mathrm{w})$, and antioxidant activity $\mathrm{IC}_{50}\left(\mathrm{y}_{4}, \%\right)$, respectively.

$\mathrm{y}_{1}=67.59+2.67 \mathrm{x}_{1}-2.66 \mathrm{x}_{2}-2.51 \mathrm{x}_{1} \mathrm{x}_{2}-2.59 \mathrm{x}_{1}^{2}-$ $3.19 \mathrm{x}_{2}^{2}$

$\mathrm{y}_{2}=76.61+1.69 \mathrm{x}_{1}-2.85 \mathrm{x}_{2}-7 \mathrm{x}_{1} \mathrm{x}_{2}-5.93 \mathrm{x}_{1}^{2}-8.44 \mathrm{x}_{2}^{2}$

$\mathrm{y}_{3}=5.37+0.29 \mathrm{x}_{1}-0.19 \mathrm{x}_{2}-0.06 \mathrm{x}_{1} \mathrm{x}_{2}+0.44 \mathrm{x}_{1}^{2}+0.24 \mathrm{x}_{2}^{2}$

$\mathrm{y}_{4}=2.02+0.13 \mathrm{x}_{1}-0.21 \mathrm{x}_{2}-0.17 \mathrm{x}_{1} \mathrm{x}_{2}+0.19 \mathrm{x}_{1}^{2}+0.12 \mathrm{x}_{2}^{2}$

The value of $\mathrm{R}^{2}$ measure how well of estimated model fits the experimental data. The $\mathrm{R}^{2}$ value of recovery of dry matter (Equation (5)), recovery of protein (Equation (6)), moisture content (Equation (7)) and antioxidant activity (Equation (8)) of the powder were $0.92,0.89,0.93$, and 0.89 , respectively. This implies that there was a high correlation between experimental values and predicted values. The correlations of these values were expressed in Figure 1. Furthermore, the p-value of these responses was 0.001 , $0.0006,0.0029,0.0026$ (Figure 1), indicating that there were significant effects from independent variables to responses. Therefore, inlet air temperatures and maltodextrin concentrations have significant effects on recovery of dry matter, recovery of proteins, moisture content and antioxidant activity of the powder.

Furthermore, the linear regressions also showed that there were interactions between two independents variables. These interactions also provide combined effects on processing recovery and moisture content of the powder. The effect of both inlet air temperatures and maltodextrin concentrations were expressed by secondorder functions. Thus, the effects of independent variables on processing recovery and moisture content were expressed as parabola model. For instances, in the investigation region, when the inlet temperatures and maltodextrin concentrations increased until a certain point, the responses will reach their optimal values. However, reductions occur when independent variables exceed their favorable points. In order to achieve optimal responses, JMP provided critical values of independent variables for all responses. The critical values are shown in Figure 1. In addition, the predicted values of responses were also calculated. The optimal inlet air temperature and maltodextrin concentration for each response also calculated and these values were similar to ones of all responses. The optimal values of responses were obtained at a temperature of $142.4^{\circ} \mathrm{C}$ and maltodextrin

Table 4. Effects of inlet air temperatures and maltodextrin concentrations on the recovery of dry matter and recovery of proteins and moisture content of the obtained powder

\begin{tabular}{|c|c|c|c|c|c|c|c|}
\hline No & $\begin{array}{l}\text { Code } \\
\text { levels }\end{array}$ & $\begin{array}{c}\text { Inlet air } \\
\text { temperatures }\left({ }^{\circ} \mathrm{C}\right) \\
\mathrm{x}_{1} \\
\end{array}$ & $\begin{array}{c}\text { Maltodextrin } \\
\text { concentrations }(\%) \\
\mathrm{x}_{2} \\
\end{array}$ & $\begin{array}{c}\text { Recovery of } \\
\text { dry matter }(\%) \\
\mathrm{y}_{1} \\
\end{array}$ & $\begin{array}{l}\text { Recovery of total } \\
\text { protein content }(\%) \\
y_{2} \\
\end{array}$ & $\begin{array}{c}\text { Moisture } \\
\text { content }(\%) \mathrm{y}_{3}\end{array}$ & $\begin{array}{c}\text { Antioxidant activity } \\
(\mathrm{mg} / \mathrm{mL}) \\
\mathrm{y}_{4} \\
\end{array}$ \\
\hline 1 & $\mathrm{a} 0$ & 133 & 20 & 59.28 & 64.31 & 6.57 & 2.77 \\
\hline 2 & -- & 135 & 19 & 60.25 & 57.37 & 6.27 & 2.57 \\
\hline 3 & -+ & 135 & 21 & 57.74 & 61.9 & 6.64 & 2.38 \\
\hline 4 & $0 \mathrm{a}$ & 140 & 18.6 & 62.72 & 60.42 & 5.31 & 2.02 \\
\hline 5 & 0 & 140 & 20 & 67.82 & 76.51 & 5.29 & 1.95 \\
\hline 6 & 0 & 140 & 20 & 67.55 & 75.63 & 5.33 & 2.02 \\
\hline 7 & 0 & 140 & 20 & 67.33 & 78.61 & 5.35 & 1.85 \\
\hline 8 & 0 & 140 & 20 & 67.76 & 75.97 & 5.49 & 2.12 \\
\hline 9 & 0 & 140 & 20 & 67.57 & 76.4 & 5.44 & 2.15 \\
\hline 10 & $0 \mathrm{~A}$ & 140 & 21.4 & 58.42 & 57.84 & 6.04 & 2.56 \\
\hline 11 & +- & 145 & 19 & 72.39 & 78.46 & 5.92 & 1.87 \\
\hline 12 & ++ & 145 & 21 & 59.84 & 54.97 & 6.05 & 2.35 \\
\hline 13 & $\mathrm{~A} 0$ & 147 & 20 & 64.27 & 63.79 & 5.58 & 2.11 \\
\hline
\end{tabular}


Actual by Predicted Plot

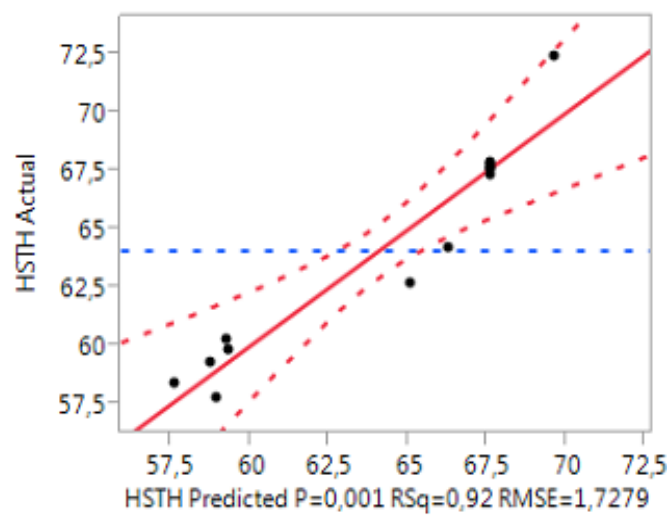

(a) recovery yield of dry matter

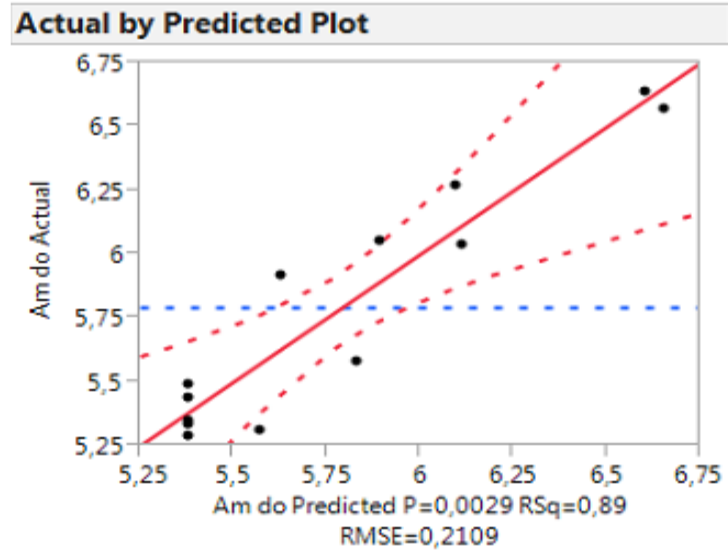

(c) moisture content of powder

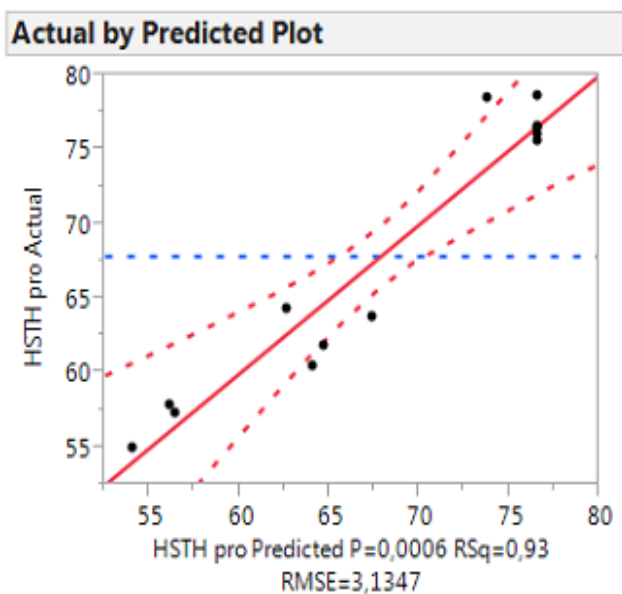

(b) recovery yield of protein content

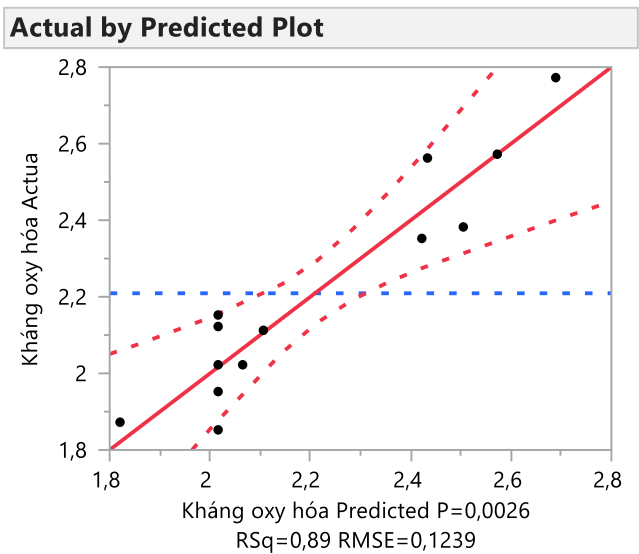

(d) powder antioxidant activity

Figure 1. Correlations between the predicted values and experimental values

concentration of $19.6 \% \quad(\mathrm{w} / \mathrm{w})$. These calculated conditions were validated by performing actual spray drying attempts. The spray drying parameters for this experiment included inlet air temperature of $142^{\circ} \mathrm{C}$, the feed flow rate of $10 \mathrm{~mL} / \mathrm{min}$, compressed air pressure of $0.2 \mathrm{MPa}$, and maltodextrin concentration of $19.6 \%(\mathrm{w} /$ $\mathrm{w})$.

The values of relevant error were lower than $5 \%$, suggesting that there was a high correlation between validated values and predicted values. Based on the values from Table 5 and the investigated values from previous experiments, the optimal parameters for spray drying of protein hydrolysate of crocodile meat were inlet air temperature of $142.4^{\circ} \mathrm{C}$, maltodextrin concentration of $19.6 \%$, and feed flow rate of $10 \mathrm{~mL} /$ $\mathrm{min}$. These conditions led to a product recovery of dry matter of $69.33 \%$, recovery of proteins of $77.18 \%$, moisture content of the obtained powder of $5.31 \%$ and powder antioxidant activity of $1.87 \mathrm{mg} / \mathrm{mL}$. The result of dry matter recovery was similar to Kurozawa et al. (2011) who studied the influences of process conditions on powder property and dryer performance and found that the product recovery at optimal conditions was $69 \%$ (Kurozawa et al., 2011). SEM imaged of crocodile powder is presented in Figure 2.
Table 5. Validated values and predicted values of responses at optimal independent variables

\begin{tabular}{lccc}
\hline \multicolumn{1}{c}{ Responses } & $\begin{array}{c}\text { Validated } \\
\text { values }\end{array}$ & $\begin{array}{c}\text { Predicted } \\
\text { values }\end{array}$ & $\begin{array}{c}\text { Relevant } \\
\text { errors }\end{array}$ \\
\hline $\begin{array}{l}\text { Recovery yield of dry } \\
\text { matter (\%) }\end{array}$ & $70.54^{\mathrm{a}}$ & $69.33^{\mathrm{a}}$ & 1.15 \\
$\begin{array}{l}\text { Recovery yield of protein } \\
(\%)\end{array}$ & $77.82^{\mathrm{a}}$ & $77.18^{\mathrm{a}}$ & 0.83 \\
$\begin{array}{l}\text { Moisture content of powder } \\
(\%)\end{array}$ & $5.38^{\mathrm{a}}$ & $5.31^{\mathrm{a}}$ & 1.34 \\
$\begin{array}{l}\text { Powder antioxidant activity } \\
(\mathrm{mg} / \mathrm{mL})\end{array}$ & $1.79^{\mathrm{a}}$ & $1.87^{\mathrm{a}}$ & 0.08 \\
\hline
\end{tabular}

Values with different superscript within the column are significantly different (Tukey's Test, $\mathrm{p}<0.05$ ).

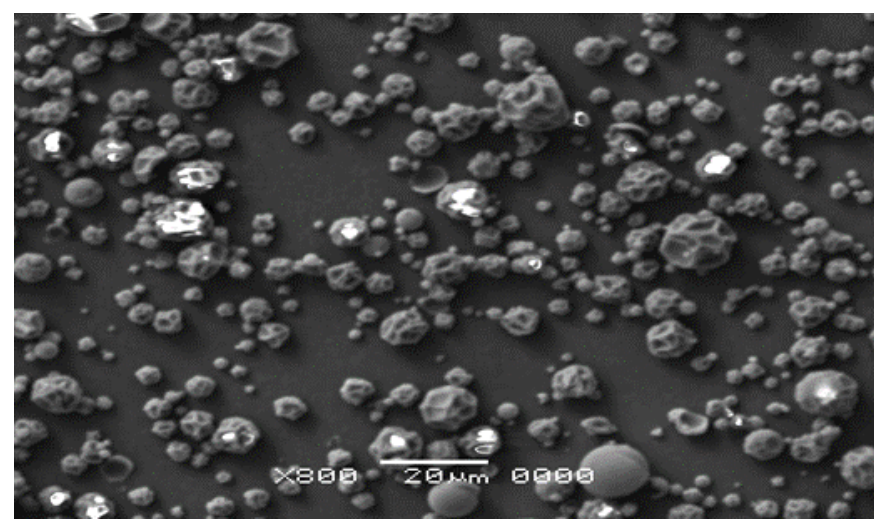

Figure 2. SEM image of crocodile powder 


\section{Conclusion}

The results of this study showed that the spray drying parameters (maltodextrin concentrations, inlet air temperatures, and feed flow rates) had significant effects on recovery of dry matter, recovery of proteins and the obtained powder properties. Inlet temperatures had significant effects on antioxidant capacity of the obtained spray-dried powder. The antioxidant capacity, expressed as $\mathrm{IC}_{50}$, of powdered obtained with spray drying at $140^{\circ} \mathrm{C}$, was $3.548 \pm 0.193(\mathrm{mg} / \mathrm{mL})$. At feed flow rate at $10 \mathrm{~mL} / \mathrm{min}$, the optimal conditions for the highest recovery of dry matter, the highest recovery of proteins, and the lowest moisture content of the powder were obtained at the inlet air temperature of $142.4^{\circ} \mathrm{C}$ and added maltodextrin concentration at $19.6 \%$. The results of this study could help establish a preliminary processing procedure for spray drying of crocodile meat protein hydrolysate. Stability of the obtained powder during storage can be studied before this powder can be produced on a larger scale for product development.

\section{Conflict of interest}

The authors declare no conflict of interest.

\section{Acknowledgments}

This research was supported by a grant for the project: "Development if value-added food products from crocodile" from the Center for Statistics and Science and Technology Information.

\section{References}

Adhikari, B., Howes, T., Shrestha, A.K. and Bhandari, B.R. (2007). Development of stickiness of whey protein isolate and lactose droplets during convective drying. Chemical Engineering and Processing, 46 (5), 420-428. https://doi.org/10.1016/ j.cep.2006.07.014

AOAC. (2005). Official methods of analysis. $18^{\text {th }} \mathrm{ed}$. Washington, DC.: AOAC.

Beilken, S., Eustace, I. and Tume, R. (2007). Analyses and nutrient composition of innovative meat industries: a report for the Rural Industries Research and Development Corporation. Australia: Australian Government.

Bhandari, B.R., Datta, N. and Howes, T. (1997). Problems associated with spray drying of sugar-rich foods. Drying Technology, 15(2), 671-684. https:// doi.org/10.1080/07373939708917253

Clare, D.A. and Swaisgood, H.E. (2000). Bioactive milk peptides: a prospectus. Journal of Dairy Science, 83, 1187-1195. https://doi.org/10.3168/jds.S0022-0302
(00)74983-6

Gómez-Guillén, M.C., López-Cabalerro, M.E., Alemán, A., López de Lacey, A., Giménez, B. and Montero, P. (2010). Antioxidant and antimicrobial peptide fractions from squid and tuna skin gelatin. Sea byProducts as a Real Material: New Ways of Application, 2010, 89-115.

Hoffman, L.C., Fisher, P.P. and Sales, J. (2000). Carcass and meat characteristics of the Nile crocodile (Crocodylus niloticus). Journal of the Science of Food and Agriculture, 80(3), 390 - 396. https:// doi.org/10.1002/1097-0010(200002)80:3<390::AIDJSFA540>3.0.CO;2-G

Jayasundera, M., Adhikari, B., Howes, T. and Aldred, P. (2011). Surface protein coverage and its implications on spray-drying of model sugar-rich foods: Solubility, powder production and characterisation. Food Chemistry, 128(4), 1003-1016. https:// doi.org/10.1016/j.foodchem.2011.04.006

Jittanit, W., Niti-Att, S. and Techanuntachaikul, O. (2010). Study of spray drying of pineapple juice using maltodextrin as an adjunct. Chiang Mai Journal of Science, 37(3), 498-506.

Kurozawa, L.E., Park, K.J. and Hubinger, M.D. (2011). Spray drying of chicken meat protein hydrolysate:

Influence of process conditions on powder property and dryer performance. Drying Technology, 29(2), $\quad 163 \quad-\quad 173 . \quad$ https:// doi.org/10.1080/07373937.2010.482711

Obón, J.M., Castellar, M.R., Alacid, M. and FernándezLópez, J.A. (2009). Production of a red-purple food colorant from Opuntia stricta fruits by spray drying and its application in food model systems. Journal of Food Engineering, 90(4), 471-479. https:// doi.org/10.1016/j.jfoodeng.2008.07.013

Re, R., Pellegrini, N., Proteggente, A., Pannala, A., Yang, M. and Rice-Evans, C. (1999). Antioxidant Activity Applying an Improved ABTS Radical Cation Decolorization Assay. Free Radical Biology and Medicine, 26(9-10), 1231-1237. https:// doi.org/10.1016/S0891-5849(98)00315-3

Samborska, K., Gajek, P. and Kamińska-Dwórznicka, A. (2015). Spray Drying of Honey: The Effect of Drying Aids on Powder Properties. Polish Journal of Food and Nutrition Sciences, 62(2), 109-118. https://doi.org/10.2478/pjfns-2013-0012

Shabde, V.S. and Hoo, K.A. (2008). Optimum controller design for a spray drying process. Control Engineering Practice, 16(5), 541-552. https:// doi.org/10.1016/j.conengprac.2007.06.004

Suetsuna, K., Ukeda, H. and Ochi, H. (2000). Isolation and characterization of free radical scavenging 
activities peptides derived from casein. Journal of Nutritional Biochemistry, 11(3), 128-131. https:// doi.org/10.1016/S0955-2863(99)00083-2

Tonon, R.V., Brabet, C. and Hubinger, M.D. (2008). Influence of process conditions on the physicochemical properties of açai (Euterpe oleraceae Mart.) powder produced by spray drying. Journal of Food Engineering, 88(3), 411-418. https://doi.org/10.1016/j.jfoodeng.2008.02.029

Wang, W. and Gonzalez De Mejia, E. (2005). A new frontier in soy bioactive peptides that may prevent age-related chronic diseases. Comprehensive Reviews in Food Science and Food Safety, 4(4), 6378. https://doi.org/10.1111/j.15414337.2005.tb00075.x

Young, J.F., Therkildsen, M., Ekstrand, B., Che, B.N., Larsen, M.K., Oksbjerg, N. and Stagsted, J. (2013). Novel aspects of health-promoting compounds in meat. Meat Science, 95(4), 904- 911. https:// doi.org/10.1016/j.meatsci.2013.04.036

Yousefi, S., Emam-Djomeh, Z. and Mousavi, S.M. (2011). Effect of carrier type and spray drying on the physicochemical properties of powdered and reconstituted pomegranate juice (Punica Granatum L.). Journal of Food Science and Technology, 48(6), 677-684. https://doi.org/10.1007/s13197-010-0195-x 